\title{
De vanskelige adverbene
}

\author{
Adverbene lurer oss ofte. Når vi bruker dem galt, endrer uttrykkene betydning. Det lille ordet falskt er joker \\ i uttrykk som falskt positive resultater. Men hvorfor skal det hete falskt og ikke falske i dette uttrykket?
}

I vår tid tilbys myriader av undersøkelser. Disse kan brukes for å fastslå både det ene og det andre. For eksempel kan man la seg teste med beintetthetsundersøkelse eller med mammografi. Eller man kan levere en prøve som undersøkes ved et mikrobiologisk laboratorium. Felles for alle undersøkelsene er at de gir resultater som vi kan stole på i større eller mindre grad - både når det gjelder sensitivitet og spesifisitet. Vi trenger presise begreper for å beskrive resultatene, både når de er til å stole på og når de ikke er det.

\section{Adverb kontra adjektiv}

Adverbene er ord som volder oss bry. Vi bruker dem ofte galt, nemlig som adjektiv. flertallsbøye de uttrykkene som vi har behov for her.

I dette farvannet brukes mange ulike kombinasjoner av ord. Heter det falske positive resultater, falsk positive resultater eller falskt positive resultater? Og tilsvarende i entall: Heter det falsk positivt resultat eller falskt positivt resultat? Det lille ordet falsk er jokeren i spørsmålene.

Uttrykkene brukes om hverandre og uten konsekvens, for eksempel i Tidsskriftet. Noen ganger benyttes falske positive resultater (2), andre ganger benyttes falskt positive resultater (3). Logikken er ikke lett å få øye på. Det lille ordet falsk volder oss åpenbart bry. I alle eksemplene skulle ordet falsk ha vært benyttet som adverb. Dette betyr at

\section{«Vi trenger presise begreper for å beskrive resultatene, både når de er til å stole på og når de ilkke er det»}

Når vi gjør dette, mister uttrykkene mening. Vi kjenner dette fra fornuftige brukte biler og fornuftig brukte biler, uttrykk som har ulik betydning. Slik som vakre flettede bånd er noe annet enn vakkert flettede bånd (1). Og en sterk rød hest høres ut til å være sterkere enn en sterkt rød hest. Tilsvarende når vi omtaler psykiatrisk sakkyndige og offentlig ansatte, meningsforskjellen er stor til psykiatriske sakkyndige og offentlige ansatte, der begge de sistnevnte uttrykkene må regnes som gale.

\section{Falske positive resultater?}

Noen ganger er det enkelt å beskrive et resultat, andre ganger er det vanskeligere. Når et resultat eller en test er positiv, betegner vi det enkelt og greit som et positivt resultat eller en positiv test. Tilsvarende er det i motsatt fall når vi sier et negativt resultat eller en negativ test. Så langt er dette plankekjøring. Negativt (eller positivt) brukes her som adjektiv. Men vi vet at tester kan mangle både sensitivitet og spesifisitet. Dette fører til at resultater kan lyve for oss; de er noen ganger ikke til å stole på. Vi har da et resultat som er falskt, altså ikke sant. Virkeligheten viser at vanskelighetene kommer byksende når vi skal kjønns- og i flertall skal det hete falskt positive resultater. Og tilsvarende i entall: Det skal hete falskt positivt resultat. Falske positive resultater bærer ikke mening. Det samme gjelder falske negative resultater.

Et søk på www.google.no på et av de korrekte utrykkene (falskt positive resultater) gir fattige 550000 treff (4). Tilsvarende antall treff for den korrekte makkeren falskt negative resultater er 320 000. Når man derimot søker på samme måte på falske positive resultater, som altså ikke er korrekt norsk, finner man mange flere treff, nemlig 41600000 . Tilsvarende antall treff for falske negative resultater, som altså heller ikke er korrekt, er også høyt, nemlig 32800000 .

\section{Falskt positive resultater}

I Arbeidsgruppen for antibiotikaspørsmål (AFA) (5) har vi i flere år hatt språktukt som eget agendapunkt. Etter å ha arbeidet med dette spørsmålet gjennom noen tid og uten å finne ut av det, kontaktet vi tre nasjonale nestorer: Finn-Erik Vinje, Sylfest Lomheim og Per Egil Hegge. Alle disse støttet oss i at ordet falsk skal stå som adverb i gjeldende uttrykk.

AFA forstår at det er vanskelig å bruke disse uttrykkene korrekt. Ikke desto mindre er det viktig. Både i mikrobiologi og innen andre felt har vi ofte behov for å omtale tester som ikke er til å stole på, og som altså er falskt negative eller falskt positive. Vi vil oppfordre alle til å benytte uttrykkene korrekt og ikke på den falske måten. I mellomtiden kjører vi bilene våre så fornuftig vi kan og klamrer oss til at de fortsatt skal omtales som fornuftig kjørte biler og ikke som fornuftige kjørte biler.

\section{Mette Walberg \\ mette.walberg@vestreviken.no \\ Smittevernavdelingen \\ Vestre Viken HF \\ 1309 Rud}

Takk til medlemmene i AFA for kritisk gjennomgang av manuskriptet, ikke minst gjennomgangen av adverbene.

Litteratur

1. Vinje FE. Riktig norsk. 2. utg. Oslo: Cappelen Akademisk Forlag, 1995.

2. Markestad T. Annonsering av forebyggende helseprogram. Tidsskr Nor Lægeforen 2006; 126: 2852-3.

3. Reinton N, Moi H, Bjerner J et al. Den svenske chlamydiavarianten nvC trachomatis i Norge. Tidsskr Nor Legeforen 2010; 130: 380-1.

4. Søkemotoren Google. www.google.no (10.1.2011).

5. Arbeidsgruppen for antibiotikaspørsmål (AFA). www.antibiotikaresistens.no (10.1.2011).

Mottatt 13.12. 2010 og godkjent 23.12. 2010. Medisinsk redaktør Raida Ødegaard.

\section{Redaksjonen kommenterer:}

Innsenderen tar opp et viktig tema og gir mange gode eksempler på feilaktig og riktig språkbruk. Konklusjonen er i tråd med praksis i Tidsskriftet, men feil kan jo ha forekommet. Emnet ble omtalt i Språkspalten i nr. 28/1990 (1), og «falskt positiv» har vært oppført i Tidsskriftets ordliste siden 1993 (2, 3). En oppfriskning av riktig bruk av adverbet falskt er bare av det gode.

\footnotetext{
Litteratur

1. Ødegaard R. Positiv eller negativ? Tidsskr Nor Lægeforen 1990; 110: 3658

2. Skikk og bruk i Tidsskriftet. Oslo: Tidsskrift for Den norske legeforening, 1993.

3. Tidsskriftets ordliste. www.tidsskriftet.no/ ?nota id=43 (14.1.2011).
} 